\title{
Kitle Kaynak Yönteminin İstihbarat Üretimindeki Yeri: Ushahidi Platformu Örneği*
}

\section{The Place of Crowdsourcing Method in Intelligence Production: Example of Ushahidi Platform}

\author{
Mert Can ATAR**
}

\section{$\ddot{O} z$}

$B u$ çalışmanın ana amacı kitle kaynak yönteminin istihbarat üretimine getirdiği yeni bakış açılar ve uygulama alanlarnnn tespit edilmesidir. Bunun için nitel araştırma yöntemi kullanılmıs, kitle kaynağın kavramsal altyapısının ve uygulama alanlarmin istihbarat üretimine ve organizasyonel yapisina yeni perspektifler getirip getirmediği sorusu üzerinde durulmuştur. Çalışma bu minvalde iki bölüme ayrlmıştır. Illk bölümde kitle kaynak kavramı irdelenmistir. Bunun için çalışmanın teorik çerçevesini de oluşturan kitlelerin bilgeliği fikri, kitlenin teknoloji ile etkileşimi ve yeni sosyal sinflar haline gelen Pro-Amatlarn ve üreketicilerin ortaya çıkışı işlenmiştir. İkinci bölümünde ise bir haber üretim platformu olan Ushahidi tantmlanmıs, 2010'daki Haiti depremi sonrasi kullanımı ve ürettiği istihbaratın mahiyeti incelenmiştir.

Anahtar Kelimeler: Kitle Kaynak, Istihbarat, Ushahidi, Kitlelerin Bilgeliği, Analiz.

\section{Abstract}

The main purpose of this study is to determine the new perspectives and application areas brought by the crowdsourcing method to intelligence production. For this, the qualitative research method was used and the question of whether the conceptual infrastructure and application areas of crowdsourcing brought new

* Bu çalışma Prof. Dr. Meltem Bostancı danışmanlığında "Haber Üretiminde Yeni Bir Yaklaşım: Gazetecilikte Kitle Kaynak Yöntemi Analizi” adlı yüksek lisans tezinden üretilmiştir.

** Doktora Öğrencisi, İstanbul Üniversitesi, Gazetecilik Bölümü, İstanbul, Türkiye, ORCID: 0000-0002-2479-8120, e-posta: tremrata@gmail.com.

Geliş Tarihi / Submitted: 13.03.2020

Kabul Tarihi / Accepted: 09.06.2020 
perspectives to intelligence production and organizational structure was emphasized. The work is divided into two parts in this way. In the first part, the concept of crowdsourcing is examined. For this, the idea of the wisdom of the crowds, which also constitutes the theoretical framework of the study, the interaction of the crowd with technology, and the emergence of Pro-Ams and prosumers, which have become new social classes, are discussed. In the second part, Ushahidi, a news production platform, was defined and its use after the Haiti earthquake in 2010 and the nature of the intelligence it produced was examined.

Keywords: Crowdsourcing, Intelligence, Ushahidi, Wisdom of Crowds, Analysis.

\section{Giriş}

İnternetin yaygınlaşmasıyla günümüzde bir bilgi patlaması yaşanmaktadır. $\mathrm{Bu}$ sebeple işi bilgilerden enformasyon üretmek olan istihbarat örgütleri ve basın kuruluşlarının doğru istihbarata ulaşması zorlaşmaktadır. Bunun yanında geleneksel yollarla ulaşılan bilgiler, kısıtlı bir bakıs açısını yansıttığından analiz edilmek istenen konulara dar bir çerçeveden bakılmasına yol açmakta, analizlerin derinliğini azaltmaktadır.

Öte yandan internet ortamındaki yoğun veri akışı, kurumların sayıca az insan gücünün altından kalkamayacağı hızda ve büyüklüktedir. $\mathrm{Bu}$ sebeple özellikle açık kaynak istihbaratından yararlanmak isteyen kurumlar için yüksek hacimli veriler büyük bir problemdir. Kitle kaynak yöntemi bu problemleri çözebilecek niteliktedir. Terim, bir kurumun karşılaştığ problemin, kendi dar profesyonel kadrosunun yönetiminde, internet ortamındaki kullanıcıların yardımıyla/ulaştırdıkları bilgilerle çözmesi olarak özetlenebilir. Nitekim kitle kaynağın, internete bağlantısı olan herkesi potansiyel bir haber kaynağına dönüştüren yapısı, doğru değerlendirmeler yapmak için sağlıklı istihbarata muhtaç olan kurumlar için önemli bir avantaj sağlamaktadır.

Buradan hareketle çalışmanın araştırma sorusu, kitle kaynağın kavramsal altyapısının ve uygulama alanlarının istihbarat üretimine ve organizasyonel yapısına yeni perspektifler getirip getirmediğidir. Bunun için nitel araştırma yöntemi benimsenmiştir. Öte yandan The New Yorker dergisi yazarı James Surowiecki'nin ortaya koyduğu kitlelerin bilgeliği fikri çalışmanın teorik altyapısını oluşturmakta, istihbarat üretim 
platformu olan Ushahidi, bu teorinin sahada test edildiği bir proje olarak değerlendirilmektedir. Çalışmanın amacı; istihbarat örgütlerinin organizasyonel yapısı için yeni bir öneri ortaya koymak ve kurumların internet kitleleri ile girecekleri olası etkileşimlerde, istihbarat edinebilecekleri yeni katılım alanlarını tespit etmektir.

\section{Kitle Kaynak Kavramı}

21. yüzyılda gelişen teknolojik araçlar sayesinde büyük ölçeklerde veri kullanıma sokulmuştur. Bu sebeple, işi haber üretmek olan basın organları çevrimiçi dönem öncesi yöntemlerle veri tasnifleyip işlemekte zorlanmaktadır. Öte yandan internet toplulukları neredeyse her konuda yüksek sayıda veri üretmekte ve bunları yararlı bilgi olarak dağıtıma sokabilmektedir. Kitle kaynak yöntemi, işte bu dağıtım sürecini belirli bir düzene sokma girişimidir.

Kitle kaynak kavramını (İngilizce “crowdsourcing”) ilk defa 2006 yılında Wired sitesinde yazar olan Jeff Howe ortaya koymuştur. ${ }^{1}$ Daren C. Brabham'ın tanımlamasına göre kitle kaynak “çevrimiçi şekilde sorumluluğu paylaştırarak problem çözmeye yarayan bir üretim modelidir. Bu kavramda sorumluluğu paylaşanlar çevrimiçi topluluklardır."2 Howe bu davranış şeklini şöyle açıklamıştır:

"Uzun zamandan beri dünyanin her tarafinda insanlar, şimdiye dek görülmemiş bir sosyal davranıs sergiliyorlar: Bu insanlar bir araya geliyor ve bir zamanlar yalnizca profesyonellere ait olan alanlarda çok az bir paraya veya karşılıksı çalışıyorlar. Bu fenomen, profesyonel fotoğrafçılıktan gazeteciliğe kadar çeşitli alanlara yayılıyor."3

Buradan anlaşılacağı gibi topluluk, kitle kaynağın temelindeki ana güçtür. Şöyle ki internet öncesi topluluklar, ulaşım imkânlarının kısıtlı olmasından dolayı coğrafi hatlar içinde oluşmuştur. İkinci Dünya Savaşından sonraki yıllarda gelişen ulaşım sistemleri, coğrafya ile belirlenmiş topluluk sınırlarını silikleştirmiştir. İnternetle birlikte topluluklar, coğrafi sınırların

${ }^{1}$ Jeff Howe, "The Rise of Crowdsourcing”, https://www.wired.com/2006/06/crowds/, (Erişim Tarihi: 18 11. 2019).

${ }^{2}$ Daren C. Brabham, Crowdsourcing, The MIT Press, Massachusetts, 2013, p. xix.

${ }^{3}$ Jeff Howe, Crowdsourcing, (çev. Günseli Aksoy) KoçSistem Bilgi ve İletişim Hizmetleri, İstanbul, 2010, s. 14. 
engellerini tamamen yok etmiştir. Bu sefer internetin içinde, coğrafi hatlar üzerindeki topluluklara benzer gruplar belirmeye başlamıştır. ${ }^{4}$

$\mathrm{Bu}$ topluluk üyeleri boş vakitlerinde profesyonel olarak yaptıkları işlerinin yanında, internet üzerinden parçası oldukları gruplarda çeşitli uğraşlar (hobiler) edinmişlerdir. Genellikle bilgisayar bağlantılı olan bu uğraşlar fotoğrafçılıktan bilimsel problemleri çözmeye kadar geniş bir çeşitliliğe sahiptir.

InnoCentive sitesi, bu yöntemin bilimsel araştırmalar alanındaki en önemli örneklerinden birini oluşturmaktadır. Site, 2002 yılında ilaç üreticisi olan Eli Lilly tarafindan kurulmuştur. Girişimin ana amacı ise zor bilimsel problemlerin kitle kaynak yöntemi ile çözülmesine olanak sağlamaktır. Bu bilimsel sorunlar biyomedikal ve bilgisayar bilimleri dâhil birçok alanı kapsamaktadır. Sitede problem çözen "çözücüler" ve probleme sahip olup bunları siteye yükleyen "arayışçılar" adlarında iki grup vardır. Çözücüler ortadan kaldırdıkları sorunlar için 5 bin dolar ile 1 milyon dolar arası para ödülü almaktadırlar. Öte yandan çözücünün ortaya koyduğu çözüm, daha sonra arayışçı şirketin fikirsel mülkiyeti altına girmektedir. ${ }^{5}$

Kitle kaynak yönteminin en çok verim getirdiği alanların başında istihbarat toplama işinin başat bir faktör olduğu gazetecilik gelmektedir. Nitekim bu yöntem sayesinde gazeteciler internet bağlantısı olan herkesi potansiyel haber kaynağı haline getirmiş ve çeşitli bilgisayımsal yöntemlerle kendilerine gönderilen girdileri kümeleyerek başarılı projeler geliştirmişlerdir. Örneğin ProPublica sitesinin (www.propublica.org) "Hasta Güvenliği” haber serisi buna iyi bir örnektir. Bu haberde site, profesyonel sağlık personellerinden aldığı verilerle bir "Cerrah Karnesi" oluşturmuştur. Bu karnenin amacı, cerrahların yaptıkları ameliyat sonucu kaç hastanın öldügünü belirlemektir. Oluşturulan veri tabanında hastalar istedikleri cerrahın istatistiklerine ulaşabilmektedir. Bu örnekte dikkat edilmesi gereken nokta, projenin ihtiyacı olan istihbaratı sağlık çalışanlarından almasıdır. Yani site, cerrah karnesini oluştururken doğrudan birincil haber kaynaklarına ulaşmayı kitle kaynak yöntemiyle başarmıştır. ${ }^{6}$

\footnotetext{
${ }^{4}$ A.g.e., s. $88-89$.

${ }^{5}$ Brabham, Ibid., p. 29-30.

' Jan Schaffer, Mimi Onuhoa, Jeanne Pinder, "Guide to Crowdsourcing”, Columbia
} 
Bununla beraber, kitle kaynak yönteminin haber kaynaklarını çeşitlendirme yetisi kamu kuruluşlarının da kullanabileceği mahiyettedir. SeeClickFix sitesi (www.seeclickfix.com), bu konuda önemli bir uygulama örneğidir. Site sayesinde insanlar, yaşadıkları yerlerdeki küçük problemleri bildirebilmektedirler. Bu problemler; yollarda ve kaldırımlarda oluşan çukurlar, çirkin duvar yazıları ya da çalışmayan trafik 1şıkları gibi şehir hayatının aksayan yönlerini kapsamaktadır. Özellikle ABD kentlerinde, şehir yöneticileri ve gazeteciler siteyi bölgede olanlar hakkında istihbarat almak için kullanmaktadır. ${ }^{7}$

\subsection{Kitle Kaynă̆ Etkileyen Faktörler}

Kitle Kaynak, verimliliğini üç adet temel olguya borçludur. Bunlar; yetkin bir kitlenin varlığ topluluklarının oluşturduğu yeni, melez ve katılımcı sosyal sınıfların doğuşudur. Bu üç olgunun birbiriyle uyumlu birleşimi, kitle kaynağın alametifarikasını ortaya çıkarmaktadır.

\subsubsection{Kitlenin Yetkinlik Doğasının Kitle Kaynak Açısından Önemi}

Kitlelerin mahareti bu yöntemin kullanılmasındaki en önemli sebeplerden biri olarak değerlendirilmektedir. New Yorker dergisi yazarı James Surowiecki'nin "Kitlelerin Bilgeliği” adlı eseri bu konuda önemli noktalara değinmektedir. Yazar bu eserinde, grupların doğru şartlar altında olağanüstü zeki olduklarını ileri sürmektedir. Ona göre kitleler, belirli şartlar altında çoğu kez içlerindeki en akıllı üyeden dahi daha akıllı olmaktadır. ${ }^{8}$

Buna kanıt olarak ise Türkiye'de de yayınlanan Kim Milyoner Olmak İster? yarışmasındaki seyirciye sorma jokeri gösterilebilir. Bu yarışmada yarışmacılara giderek zorlaşan sorular sorulmaktadır. Eğer yarışmacılar art arta 15 soruyu doğru yanıtlarsa 1 milyon dolar para ödülü kazanmaktadırlar. Yarışmacılar zorlandıkları sorularda kullanmak için üç jokere sahiptirler. Bunlardan birinde dört adet seçenek ikiye indirilir. Bir diğerinde yarışmacı, zekâsına güvendiği bir uzmanı arar. Üçüncüsü ise

Fournalism School, 2016, s. 37-38, https://core.ac.uk/download/pdf/161457016.pdf, (Erişim Tarihi: 20.02.2020).

${ }^{7}$ Brabham, Ibid., p. 32.

8 James Surowiecki, Kitlelerin Bilgeliği, (çev. Osman Deniztekin), Varlık Yayınları, İstanbul, 2007, s. 11. 
sorunun izleyicilere sorulduğu ve doğru şıkkın stüdyodaki seyirciler arasında oylandığı jokerdir. Bunların arasında doğru yanıtı en isabetli tespit edebilen joker ise seyirciye sorma jokeridir. Şöyle ki uzmanlar, doğru cevabı yüzde 65 oranında tutturuyorken, izleyicilerden oluşan kitle yüzde 91 seviyesinde doğru cevabı vermektedir. ${ }^{9}$

Bir diğer örnek olarak ABD'ye ait Scorpion denizaltının bulunma yöntemi gösterilebilir: 1968 yılının mayıs ayında Scorpion adındaki ABD denizaltısı Kuzey Atlantik'ten Nerwsport Nerws'e dönüş yolunda kaybolmuştur. ABD donanmasının denizaltının son konumunu bilmesine rağmen ona ne olduğu hakkında hiçbir fikri yoktur. Aranacak alan ise yirmi mil genişliğinde ve binlerce ayak derinliğinde bir çemberdir. ABD yönetiminin kayıp denizaltıyı bulması için görevlendirdiği kişi ise John Craven adındaki bir donanma subayı olmuştur.

Craven öncelikle denizaltının nasıl battığı ile ilgili bir dizi senaryo üretmiştir. Daha sonra matematikçilerden ve denizaltı kurtarma uzmanlarından oluşan bir ekip kurmuştur. Onlardan sorunun çözümü için birbirlerine danışmalarını değil, bağımsız olarak kendisinin ürettiği senaryolardan hangisinin en isabetli olacağına dair tahmin yürütmelerini istemiştir. Planı, bu tahminleri bir araya getirmek ve Scorpion'un nasıl yok olduğuna dair iyi bir fikir edinmektir. Craven tüm tahminleri topladıktan sonra bayes teoremini kullanarak ortalama bir konum ortaya çıkarmıştır. $\mathrm{Bu}$ yöntem olumlu sonuç vermiş ve denizaltı, grubun tahmininden 220 yard (201 metre) uzağında bulunmuştur. Burada üzerinde durulması gereken nokta; Scorpion'un bulunmasını sağlayan nihai tahminin grubun herhangi bir üyesinin seçtiği bireysel çıkarımın değil, kolektif bir yargının ürünü olmasıdır. ${ }^{10}$

Kitlenin bu örnekteki mahareti grubun bazı özellikleri bünyesinde toplamasının bir sonucudur. Surowiecki'ye göre bir kitlenin verimli olabilmesi için; farklı alanlardan gelen kişilerin oluşturacağ fikir çeşitliliğine, bu fikir çeşitliliğini besleyecek ve üyelerin bağımsız olmasını sağlayacak

\footnotetext{
${ }^{9}$ A.g.e., s. 23-24.

${ }^{10}$ Sherry Sonntag, Christopher Drew, Blind Man's Bluff, Public Affairs, New York, 1998, 145-150'den aktaran James Surowiecki, Kitlelerin Bilgeliği, Varlık Yayınları, İstanbul, 2007, s. 17-19.
} 
özgür bir ortama, insanların yerel bilgiler üzerine yoğunlaşabilecekleri âdemi merkeziyetçi bir sisteme ve bireysel çalışmaları koordine edip bir sonuç çıkartacak otoriteye ihtiyaç duyulur. Eğer grup, bu dört özelliği de bünyesinde barındırırsa yapılan tahminlerin ortalaması, olası hataları telafi edebilecektir. ${ }^{11}$

$\mathrm{Bu}$ dört ana özellik kitlenin bilgeliğini ayakta tutan sütunlar olarak görülebilir. Öyle ki birinin eksik olması başarısız sonuçlar için yeterli bir sebeptir. Bu konuda ABD'nin istihbarat ve karar alıcı organlarının yaptıkları hatalar iyi örnekler teşkil etmektedir. Nitekim fikir çeşitliliği az olursa ne olur sorusunun cevabı, ABD'nin 1961 senesinde yaptığ Körfezi Çıkarması'na bakılarak anlaşılabilir.

Burada Kennedy yönteminin yaptı̆̆ olmayacağını dair hesap yapma görevini, harekâtın aynı zamanda planlayıcısı olan ekibe vermesi olmuştur. Bu hamle ihtiyat çağrısı yapan muhaliflerin susturulmasını yol açmış ne CIA'e ne de Dışişleri Bakanlığı'nın Küba Masası'na danışılmıştır. Sonuç olarak harekât başarısız olmuştur. Burada kaçırılmaması gereken nokta hemen hemen aynı arka plana sahip grup üyelerinin, çatışmasız biçimde birbirleriyle kaynaşmasıdır. Böylelikle kitle, dışarıdan gelen farklı fikirlere karşı direnç kazanmıştır. Howe, çatışmasız grupların akıbetini şöyle değerlendirmektedir:

“Görüşmek ve tartışmak, kolektif zekânın düşmanıdır, çünkü çeşitliliği azaltır. Bireyler konuştukça uzlaşma yolu açılır. Kalabalığın akıllı tahminlerde bulunabilmesine veya bir probleme yeni yaklaşımlar bulabilmesine olanak tanyan ana koşullardan biri özerkliktir. Her bireyin bağımsız olarak seçimini yapması gerekir." 12

Ayrıca bu tür homojen gruplar, üyelerinin fikirsel bağımsızlı̆̆ını da tehlikeye atmaktadır. Zira çoğunluğu aynı fikirde olan bir grup, içeriden gelecek farklı fikirlere tıpkı dişarıdan gelenlere olduğu gibi direnç gösterecek ve olası bir muhalefeti kısa sürede etkisiz hale getirecektir. ${ }^{13} \mathrm{Bu}$ durum kitlenin verimliliğine büyük zarar vermektedir. Çünkü bağımsızlık,

${ }^{11}$ Surowiecki, a.g.e., s. 29-30.

${ }^{12}$ Howe, a.g.e., s. 145.

${ }^{13}$ Surowiecki, a.g.e., s. 54-56. 
insanların yaptıkları hataların birbirleriyle ilişkilendirilmesini engellemektedir. Yani yapılan hatalar sistematik olarak aynı yönde olmayacağından, kolektif yargı etkilenmeyecektir. $\mathrm{Bu}$ da doğru sonuca ulaşma şansını arttıracaktır. ${ }^{14}$

Bunun yanında İkinci Dünya Savaşı sonrasında ABD'nin istihbarat örgütü CIA'in nasıl örgütlenmesi gerektiğine dair yapılan tartışmalar, bize kurumlardan oluşan kitlenin nasıl verimli bir şekilde çalıştırılabileceği konusunda fikir vermektedir.

Özellikle âdemi merkeziyetçilik ile merkeziyetçilik arasındaki avantaj ve dezavantaj tartışmaları bu sürecin ana maddesi olmuştur. Tartışmanın başlangıcı İkinci Dünya Savaşının hemen sonrasına kadar gitmektedir. Savaştan önce ABD istihbarat örgütlerinin genel yapısı birbirinden ayrı ve irtibatsız bir görüntü vermekteydi. Ülkenin istihbarat ihtiyacı farklı silahlı kuvvetlerin farklı istihbarat kolları tarafından karşılanmaktaydı. Bu sistemin verimliliğini tartışmaya açacak olan olay ise 7 Aralık 1941 yılında gerçekleşen Pearl Harbor baskını olmuştur.

Yaşanan felaketin ardından devlet bünyesinde yapılan görüşmelerin sonucunda $\mathrm{ABD}$ istihbarat sisteminin yetersiz olduğuna karar verilmiş ve Amerikan Kongresi, 1947 senesinde Ulusal Güvenlik Yasası'nı çıkararak Merkezî İstihbarat Örgütü'nü (CIA) kurmuştur. Ancak burada ABD istihbaratının merkezileştirilmesi amacı gerçekleştirilememiştir. Bunun nedeni CIA yöneticisinin sadece kâğıt üzerinde ABD istihbarat örgütlerinin başında olmasıdır. İstihbarat örgütleri aslında, özerk sayılabilecek bir kurumlar kümesi haline getirilmiştir. ${ }^{15}$

ABD kamuoyu bu gerçeği 11 Eylül 2001 tarihinde gerçekleşen terör saldırılarından sonra idrak edecektir. Saldırıyı soruşturan 11 Eylül Soruşturma Komisyonu yayınladığ 13 . Rapor bu durumu açıklamıştır. Komisyona göre en büyük problem farklı istihbarat örgütleri arasındaki enformasyon paylaşımı eksikliğidir. Çözüm, “Akıllı bir hükümet, düşmanı

\footnotetext{
${ }^{14}$ A.g.e., s. 59.

${ }^{15}$ A.g.e., s. $83-84$.
} 
bir bütün olarak görmek için tüm bilgi kaynaklarını birleştirir” denilerek vurgulanmıştır. ${ }^{16}$

Raporla aslında âdemi merkeziyetçi bir organizasyonun nasıl başarılı olabileceği idrak edilmiştir. Âdemi merkeziyetçi yapı, yalnızca kurumların elde ettiği bilgileri kümeleyecek ve kapsamlı bir analiz çıkartacak üst bir kurum bulunduğu takdirde başarılı olmaktadır. Diğer bir deyişle ABD istihbarat çevreleri, 11 Eylül saldırılarını âdemi merkeziyetçi bir sistem benimsedikleri için değil, örgütlerin topladığı enformasyonu kümeleyecek hiçbir kurumun olmaması sebebiyle öngörememiştir. Yani ortada FBI ajanlarının, CIA analistlerinin ve Ulusal Güvenlik Örgütü uzmanlarının biriktirdiği enformasyonu, kolektif bir yargı haline getirecek üst bir merci bulunmamaktadır. ${ }^{17}$

Âdemi merkeziyetçilik konusunda ABD’li iktisatçı Friedrich A. Hayek'in görüşleri dikkate değerdir. Hayek, "Bilginin Toplumda Kullanımı" makalesinde kapalı bilgi ve "soruna yakın kişı" diye tanımladığı iki olgudan bahsetmektedir. Kapalı bilgi belirli bir yer, iş ya da deneyime özgü olduğu için kolaylıkla özetlenip başkalarına iletilemeyen ve çok değerli bilgi olarak tanımlanabilir. Bu bilgiler istatistiki veriler olarak dahi değerlendirilemez. "Soruna yakın kişi" ise ortaya çıkan sorunlara en yakın olan, bu sebeple de o sorunun çözümünü bilme olasılığı en yüksek kişidir. Hayek'e göre bir kişi soruna ne kadar yakınsa, sorunla ilgili kapalı bilgiler edinmesi, dolayısıyla bu bilgileri kullanıp sorunu çözmesi o kadar kolaylaşmaktadır. ${ }^{18}$

Kitlelerin bilgeliği fikri âdemi merkeziyeti bir veri ve bir yarar olarak kabul etmektedir. Buradan hareketle, sadece kendi çıkarlarını gözeten bağımsız insanlardan oluşan bir kitlenin çabalarını tepeden yönlendirmek yerine, kurum ya da kişi topluluklarının aynı sorun üzerinde âdemi merkeziyetçi bir tarzda çalışmalarını yürütmeleri, alınacak kararların daha sağlıklı olmasına yardım edecektir. Ancak burada dikkat edilmesi nokta

16 "How to Do it? A Different Way of Organizing Government", http://govinfo. library.unt.edu/911/report91Report_Ch13.htm, (Erişim Tarihi: 18.11.2019).

17 Surowiecki, a.g.e., s. 93-94.

18 Fried A. Hayek, "The Use of Knowledge in Society", The American Economic Review, 1945, Vol. 35, No. 4, 519-539, p. 524-525. 
ABD karar alıcılarının istihbarat örgütlerinin organizasyonu konusunda yaptıkları hataya düşmemek ve sistemin bir bölümünde üretilen enformasyonun, geri kalan bölümlere de yayılmasını sağlamaktır. ${ }^{19}$

Kitleler her ne kadar doğru şartlar altında üstün bir performans sergilese de birbirleriyle rahat bir iletişim içinde olacakları ve karşılıklı çıkar ilişkilerini adilce düzenleyebilecekleri platformlara ihtiyaç duymaktadırlar. Kitlenin bilgeliğinin bu arayışına teknoloji cevap vermiştir. İnternetle kitleler, kendilerini ifade edebilecekleri kullanışlı kanallar bulmuşlardır.

\subsubsection{Kitlenin Teknoloji ile Etkileşimi}

Açık kaynak kodlu yazılımlar teknolojinin, kitlelerin etkinliğini arttırması bakımından önemli örneklerdir. Bu üretim türü internetin ilk ortaya çıktığı dönemlerden beri revaçta olan bir yazılım geliştirme sistemidir. $\mathrm{Bu}$ yazılımlar, dar bir mühendis ya da bilim insanı kadrosu tarafından değil, internete bağlı ve farklı arka planlara sahip kişiler tarafından geliştirilmektedir. İnternetteki kullanıcılar açık kaynak kodlu yazılımları geliştirmek için bir araya gelmekte, proje üretmekte ve bilgi paylaşımı yapmaktadır. Bu yazılım etrafında birleşen insanların en önemli özelliği ise tüm bunları gönüllülük esasına göre yapıyor oluşlarıdır. ${ }^{20}$

Açık kaynak yazılımlarının geliştirilme yöntemi, internet ortamında kitleden güç olarak yapılan ilk uygulamalardan biri olarak görülebilir. $\mathrm{Bu}$ yazılımlar ilk defa ABD'de 1960'lar ve 1970’lerde ortaya çıkmıştır. Bilgisayar programlamasının erken dönemlerinde yazılımcılar istedikleri programları ya kendileri yazmışlar ya da yazmaları için insanları tutmuşlardır. Yazılımların tümü şirketlerin ya da üniversitelerin laboratuvarlarında mühendisler ve bilim insanları tarafından üretilmiştir. Burada dikkat edilmesi gereken nokta; yazılımcıların ürettikleri ürünleri diğerleriyle herhangi bir ücret talep etmeden paylaşmıs olmalarıdır. Yazılan bir yazılımı başka bir bilim insanına ya da mühendise vermek ve ürünün o kişi tarafından tekrar elden geçirilmesi normal bir uygulama olarak görülmüştür. Zamanla bu komünal davranış şekli bir tür "hack kültürü” oluşturmuştur.

\footnotetext{
${ }^{19}$ Surowiecki, a.g.e., s. 87-88.

20 Sadi Evren Şeker, "Kitle Kaynak (Crowdsourcing)", http://mis.sadievrenseker.com/ 2015/04/kitle-kaynak-crowdsourcing/, (Erişim Tarihi: 12.02.2020).
} 
Hacker terimi o dönemlerde bu tür faaliyetlerin genel adı olmasından ötürü negatif bir anlam taşımamaktadır.

1969 senesinde ABD Savunma Bakanlı̆̆ı'na bağlı Savunma İleri Araştırma Projeleri Ajansı ilk kıtalararası yüksek hızlı bilgisayar ağı olan ARPANET'i kurmuştur. Bu ağ zaman geçtikçe birçok üniversiteyi ve araştırma laboratuvarını birbirine bağlamıştır. Bununla birlikte hackerlar yazılım kodlarını, hatta yazılımların kendisini çok daha rahat şekilde birbirleriyle paylaşmaya başlamıştır. Hackerların kendilerine özgü davranış normları bu dönemde şekillenmiştir.

Hacker kültürünün en yoğun yaşandığı yerlerden biri de MIT'nin (Massachusetts Institute of Technology) bünyesindeki Yapay Zekâ Laboratuvarı olmuştur. Ancak 1980 yılında bu kültür, bir grup çalışanın bazı yazılım kodlarını lisanslamasıyla darbe almıştır. Bu işlemle birlikte lisanslanan kodlar daha önce olduğu gibi herkese açık olmayacak, sadece yazılım sahipleri tarafından kullanılabilecektir.

$\mathrm{Bu}$ durumdan en çok rahatsız olan kişi MIT'de programcı olarak çalışan Richard Stallman olmuştur. Stallman yazılımların ve kodların ücretli hale gelmesini ahlaken yanlış olduğu düşünmüş, bu sebeple 1985 senesinde Özgür Yazılım Kuruluşu (Free Software Foundation) adlı bir kurum kurmuştur. Bu kurumun amacı hackerlar tarafından üretilen yazılımlara ücretsiz erişimi garanti altına alacak yasal bir mekanizma kurmaktır. Bu amaçla üretilen lisansın adı Genel Kamu Lisansı olarak belirlenmiştir (General Public License ya da GPL). Genel Kamu Lisans1, kodların ücretsiz şekilde elde edilmesini, üzerinde çalışılmasını, modifiye edilmesini ve dağıtılmasını garanti altına almıştır. ${ }^{21}$

Açık kaynak yazılımlarının nasıl işlediğini görmek için Apache web sunucu yazılımina bakılması yeterlidir. Yazılım, ilk defa Illinois Üniversitesinde lisans öğrencisi olan ve daha sonra Ulusal Süper Hesaplama Uygulamalar1 Merkezi'nde (National Center for Supercomputing Applications) çalışmış Rob McCool tarafından geliştirilmiştir. Amacı, web sitesi sahiplerinin istedikleri dosyaları ve içerikleri internet üzerinden yayınlamalarını sağlamaktır. McCool yazılımı geliştirmekle kalmamış, geliştirdiği her sürümü

${ }^{21}$ Eric von Hippel, Democratizing Innovation, The MIT Press, Massachusetts, 2005, p. 97-98. 
internet üzerinden indirilebilir hale getirmiştir. Böylelikle internetteki diğer kişiler yazılımı indirmiş, modifiye etmiş ve geliştirmişlerdir.

McCool'un 1994 yılında USHUM'den ayrılması, yazılımın geliştirilme aşaması sekteye uğratmamıştır. Bunun yerine süreç küçük bir site yöneticisi grubu tarafından devam ettirilmiştir. Bu yazılımcılar Apache'yi kendi sitelerinde kullanarak geliştirmeye devam etmişlerdir. Yöneticilerin sekiz kişilik çekirdek kadrosu, yazılımı sürekli yamalarla iyileştirmiştir. Sonunda Apache 1 Aralık 1995 senesinde tam sürüme geçmiştir. Bugün bu yazılım, dünyanın en çok kullanılan web sunucularından biridir. Karşılarında Microsoft ve Netscape gibi güçlü şirketler bulunmasına rağmen Apache, açık kaynak yazılımı olması sebebiyle piyasada halen büyük bir pay sahibidir ve halen geliştirilmeye devam edilmektedir. ${ }^{22}$

Açık kaynaklı yazılımların üretilmesi ve geliştirilmesi sadece bilgisayar yazılımları gibi sanal ürünlere özel değildir. Bu yöntem fiziksel ürünler için de kullanılmaktadır. Don Tapscott ve Anthony D. Williams'ın yazdı̆̆ "Wikinomics" (Türkçe Vikinomi) adlı eser; teknolojiyle desteklenen şirket gruplarının iş birliğine dayanan ve yeni ekonomik üretim modelini anlatan bir kavram ortaya koymaktadır. Buna göre günümüzde artık şirketler, projelerini içlerine kapanarak gerçekleştirmemektedirler. İşi uçak tasarlamak veya hastalıklara ilaç üretmek olan birçok şirket, diğer şirketlerle yapacakları uluslararası iş birliklerine daha sıcak bakmaktadır. $\mathrm{Bu}$ iş birliği kolektif zekânın, kabiliyetin ve kaynakların paylaşılmasıyla beraber hiyerarşik olmayan yatay bir ağ içerisindeki katılımcıların ortak çalışması ile gerçekleşmektedir. Birden fazla şirketin oluşturduğu bu iş birlikleri tek bir şirketin başarabileceğinden daha fazla hedefi başarabilmektedir. ${ }^{23}$

Vikinomi'nin temelinde dört adet faktör vardır. Bunlar şeffaflık, paylaşım, küreselleşme ve kolektif üretimdir. ${ }^{24}$ Şeffaflıktan kastedilen, şirketlerin önceden sır olarak görülen bilgileri ve araçları kendilerine saklamakta daha isteksiz olmalarıdır. Bunun nedeni yeni dönemde bilgilerin, şirket ile teması olan ortaklara, çalışanlara, müşterilere ve hisse sahiplerine açılmasının saklanmasından daha çok avantaj sağlamasıdır.

\footnotetext{
${ }^{22}$ Ibid., p. 101.

${ }^{23}$ Don Tapscott, Anthony D. Williams, Wikinomics, Penguin Books, London, 2006, p. 18.

${ }^{24}$ Ibid., p. 20.
} 
Çünkü şeffaflığa önem veren şirketin ortakları, çalışanları ve müşterileri söz konusu şirketi buna önem vermeyen diğer şirketlere kıyasla daha kolay analiz edebilmektedir. Diğer yandan hisse sahipleri yatırım yaptıkları şirketleri daha kolay gözlemleyebilmekte, güvenilirliği yükselen bu şirketlere daha fazla yatırım yapabilmektedir. Şeffaf bir şirketin çalışanları da bu durumdan pozitif etkilenmektedir. Zira böylesi bir iş ortamında çalışanlar, kurumlarını daha çok benimsemektedir.

Kitlesel üretim ise açık kaynak kodlu yazılımların geliştirilmesi yönteminin Vikinomi'ye uygulanmış hali olarak görülebilir. Bu yöntemde fiziki veya dijital ürünler, hiyerarşik olmayan yatay bir organizasyonun gönüllü katılımcıları tarafından üretilir. Bu yöntemin en iyi örnekleri Linux ve Apache yazılımlarıdır. ${ }^{25}$

Paylaşım faktörü, şirketlerin iş yapış yöntemlerinde tescilleri altında bulunan mal ve fikirler konusunda daha esnek davranmalarını temel alır. Örneğin 1999 yılında bir düzine ilaç firması, fikir mülkiyetlerini ellerinde bulundurdukları ar-ge projelerini terk etmiş ve SNP Konsorsiyumu gibi açık iş birliğini temel alan projelere destek vermiştir. Bu iki projede de biyomedikal araştırmalarla elde edilen ve halka açık veri tabanlarında bulunan genetik bilgiler toplanmıştır. Çalışma ile birlikte moleküler biyolojinin yardımıyla kişiye özel hazırlanması planlanan ilaçların üretimine yol açılmıştır. Şirketler bu başarıyı, üretecekleri potansiyel ürünlerin tescil haklarından feragat etmeden ve temel fikir mülkiyeti haklarını ellerinde tutarak başarmıştır. Burada dikkat edilmesi gereken nokta, paylaşım faktörünün şirketlerin kritik önemdeki mal ve fikirlerinin paylaşılmasını değil, fikri mülkiyet altındaki bilginin adil bir şekilde ortaklar arasında dağıtılmasını desteklediğidir. ${ }^{26}$

Küreselleşme olgusu da Vikinomi kavramı altında farklı bir anlama sahiptir. Şöyle ki bu kavramda şirketlerin çok uluslu olmaları onları küresel yapmaya yetmemektedir. Klasik anlamda çok uluslu bir şirket her ülke içinde kendi başına hareket edebilen bir federasyon şeklinde örgütlenmiştir. Bu federasyona bağlı her bir dal (farklı ülkelerdeki şubeler),

\footnotetext{
${ }^{25}$ Ibid., p. 22-23.

${ }^{26}$ Ibid., p. 26-27.
} 
kendi ürünlerini yerel ihtiyaçlara göre şekillendirmektedir. Ancak bu daha önce de belirtildiği gibi, şirketin küreselleşmiş olduğu anlamına gelmemektedir. Bu bağlamda olması gereken; ürünlerin küresel bir operasyon ile dizayn edildiği, kaynak aktarımının yapıldığ ve dağıtıldığı genel bir ekosistem yaratmaktır. ${ }^{27}$

Vikinomi kavramını en iyi temsil eden somut örnek, alışveriş sitesi olan Amazon'dur. Dünyanın en büyük perakende satıcısı olan Amazon, şu anki büyüklügüne iki olguyu destekleyerek ulaşmıştır: İnovasyon ve viral büyüme.

İnovasyon her şirketin en önemli önceliklerinden biridir. $\mathrm{Bu}$ sebeple tüm şirketler her yıl ar-ge çalışmaları için bütçelerinin önemli bir bölümünü ayırır. Ancak bu çabalara rağmen inovatif fikir ve servislerin bulunması garanti altına alınamaz. Amazon bu konuda klasik tarzda iş yapan şirketlerden farklı bir yol seçmiştir. Şirket, ar-ge işini geliştirici topluluğuna ve küçük/orta büyüklükteki şirketlere bırakmıştır.

Bunu yaparken Amazon, U.P.A.'sını (Uygulama Programlama Arayüzü) e-ticaret motoruna açmıs, böylelikle kullanıcılarına platformu beraber şekillendirme şansı vermiştir. Daha açık bir ifade ile kullanıcılar, siteye yüklemek istedikleri özellikleri kendileri geliştirip sitede kullanabilmektedirler. Şirket, böylelikle sitedeki müzik CD’lerini kataloglayan web sitesi ve mesajlaşma yoluyla istenilen ürünün linkini kullanıcılara ulaştıran programlar gibi kullanıcı kaynaklı servisleri neredeyse hiçbir maliyet ödemeden elde edebilmiştir.

Bunların yanında Amazon, geliştirdiği araçlar ve sahip olduğu veriler konusunda fazlasıyla paylaşımcıdır. Amazon'un web servislerinden sorumlu Jeff Barr bu konuda şöyle söylemektedir:

"Geliştiricilerin eline ne kadar fazla veri verirsek o kadar fazla ve ilginç araçlar, siteler ve uygulamalar gelistirilecek ve bunlar ne kadar fazla olursa Amazon'a olan katkllar o kadar fazla olacak. Daha fazla trafik ve tıklanma alacağız, bunun sonucunda da fazla satış gerçekleşecek. ”28

\footnotetext{
${ }^{27}$ Ibid., p. 29-30.

${ }^{28}$ Ibid., p. 196.
} 
Daha fazla trafik ve şirketin büyümesindeki en önemli etkenlerden biri olan tıklanma, viral büyüme ile doğrudan bağlantılıdır. Sirketin "bağlantılı programlar" sistemi, site dışı ortaklarla beraber Amazon'a büyük bir ticaret ağı kazandırmış durumdadır. Yüzlerce site, şirket ile yaptıkları anlaşmalarından dolayı ziyaretçilerini Amazon'a yönlendirmektedir. Bunun karşılığında ise yapılan satışlardan komisyon almaktadırlar. ${ }^{29}$

Görüldüğü gibi gücünü kitleden alan projeler teknolojinin gelişmesiyle paralel olarak yükselmektedir. Kitle kaynak, açık kaynak kodlu yazılımlar ve Vikinomi, aslında aynı temelden hareket etmektedir. Bu temel; coğrafi ve teknolojik nedenlerden ötürü daha önce örgütlenme ve iş birliği yapma şansı olmayan kurum ve kişilerin, internetin sunduğu özgür bilgi paylaşımı ve üretimi ortamından yararlanılabilmesidir. $\mathrm{Bu}$ sebeple internet ortamında oluşturulan grupların niteliği, kitle kaynağın önemli bir kısmını oluşturmaktadır.

\subsubsection{Internet Topluluklar}

Kitle kaynağın gücünü aldığı çevrimiçi topluluklar çok çeşitli olsa da özellikle Pro-Amatlar ve üreketiciler bu yöntemde başat roller oynamaktadır. Öncelikle; tıpkı üreketiciler gibi melez ve katılımcı bir sosyal sınıf olan ProAmat'ları anlamak için amatörlük kavramının incelenmesi gerekmektedir. Bu konuda iStockphoto örneği önem taşımaktadır. Site 2000 yılında Bruce Livingstone tarafından, diğer tasarımcılarla fotoğraf paylaşabilecekleri bir platform yaratmak için kurulmuştur. Burada amatör fotoğrafçılar eserlerini satışa çıkartabilmişlerdir. Livingston her fotoğraf için 25 cent talep etmiş, fotoğraf satıldığında paranın bir bölümü kendisine, bir kısmı da fotoğrafçıya gitmiştir. iStockphoto'nun alametifarikası ise site müdavimlerinin çoğunluğunun amatörlerden oluşmasıdır. ${ }^{30}$

iStockphoto gibi hizmetlerden önce, amatörler, kalitesi ne olursa olsun fotoğraflarını kolayca satamamıslardır. Bu sebeple pazar, tamamen profesyonellerin kontrolünde şekillenmiş ve fotoğrafçılar ürünlerine biçtikleri ücretleri bu doğrultuda belirlemiştir. Örneğin Howe'un belirttiğine göre Ulusal Sağlık Müzesindeki bir proje direktörü grip hastalarının

\footnotetext{
${ }^{29}$ Ibid., p. 194-196.

${ }^{30}$ Howe, a.g.e., s. 13-14.
} 
fotoğraflarını istediğinde, profesyonel bir fotoğrafçı, fotoğraf başına 100 dolar ücret talep etmiştir. Ancak iStockphoto'da aynı fotoğraf için istenen ücret yalnızca 1 dolardır. İşte profesyonel ile amatör arasındaki farkın belirlenmesi ve amatör kelimesinin tanımı bu sebeple önem kazanmıştır. ${ }^{31}$

Charles Leadbeater ve Paul Miller'in yazdıkları "Pro-Amat Devrimi: Şevk, Ekonomimizi ve Topluluğumuzu Nasıl Şekillendiriyor?” kitabında yazarlar, amatör kelimesinin "beceriksiz" ya da "deneyimsiz" algısının artık doğruyu yansıtmadığını savunmaktadır. Yazarlar; teknolojinin yardımıyla kendilerini eğitmiş, bilgilendirmiş, örgütlenmiş ve proje geliştirmiş bu insanları, profesyonel ve amatör kelimelerini birleştirerek Pro-Amat olarak tanımlamıştır. ${ }^{32}$

Buna göre Pro-Amat'lar amatör olarak yaptıkları işlerle, genelde profesyonel olarak yaptıkları işten arta kalan boş vakitlerinde ilgilenmektedirler. $\mathrm{Bu}$ zamanlar genelde insanlar günün yorgunluğunu attıkları iyileşme vakitleridir. Yaptıkları işi istedikleri zaman bırakabilecekleri hissi insanlara zamanlarının üzerinde kontrol sahibi oldukları hissi verdiğinden, bir doyum duygusu oluşturmaktadır.

Bunun yanında Pro-Amat'lar gelirlerinin küçük bir kısmını amatör olarak yaptıkları işe harcamaktadırlar. Harcanan bu küçük paralar bile yarın aynı işi tekrar yapma isteğini tetiklemektedir (amatör fotoğrafçıların kendilerine ucuz bir fotoğraf makinesi alması buna örnek olarak görülebilir). Bunun yanında yaptığı işte ilerleyen bir Pro-Amat asla tek başına kalmak istememektedir. Örneğin Pro-Amat fotoğraf sanatçıları, sadece fotoğraf çekmekle kalmamakta, aynı zamanda bu fotoğrafları internetin sağladığı platformlarla diğerlerine göstermekte (iStockphoto gibi platformlar aracılığıyla), hatta bu eserlerden para kazanmaya çalışmaktadır. ${ }^{33}$

Tüm bu eylemler Pro-Amat'lar arasında bir tür kültür sermayesi oluşturmaktadır. Kültür sermayesi terimi ilk defa Fransız sosyolog Pierre Bourdieu tarafından kullanılmıştır. Ona göre insanların kullanımında olan dört adet sermaye vardır. Bunlar; finansal, insani (bilgi ve yetenek),

\footnotetext{
${ }^{31}$ Clay Shirky, Here Comes Everybody, The Penguin Press, London, 2008, p. 81.

${ }^{32}$ Charles Leadbeater, Paul Miller, The Pro-Am Revolution, Demos, London, 2004, p. 12.

${ }^{33}$ Ibid., p. 21-22.
} 
sosyal ve kültürel sermeyelerdir. Bunlardan biri olan kültürel sermaye, kültürel etkinliklerde yer alabilme imkânıdır. Örneğin müzeye gitme ve tiyatro izleme bunun içinde yer alır. Bourdieu kültürel sermayenin bireyi özel ve biricik kıldığını söylemiştir. Bu bakımdan Pro-Amat'lar kültürel sermaye bakımından zengindir. ${ }^{34}$ Bunun bir sonucu olarak kültür sermayesi Pro-Amat'lara bir tür aidiyet duygusu vermektedir. Böylelikle bu kişiler diğer grup üyeleri ile oyunlar oynar, yarışır ve karşılıklı performans sergilerler. Bu durum, organizasyon içinde kültürel sermaye ile birlikte sosyal sermayeye de katkıda bulunur.

Ancak bir grubun kültür sermayesine katkıda bulunması topluluğun, Pro-Amat'lardan oluştuğu anlamına gelmemektedir. Bunun içi bazı özel şartların bir araya gelmesi gerekir. Bir sosyal organizasyonun Pro-Amat aktivitesi olması için ilk başta kurslar, antrenmanlar ve provalar aracılığıyla bilgi/yetenek üretimi ve bunların diğer üyelere aktarımının yapılması gerekir. Ayrıca performanslar aracılığı ile grup üyelerinin birbirini tanımasına olanak vermek, grup içi aktiviteler düzenlemek ve topluluk üyelerinin diğer insanlardan farklılaşmasını sağlamak önemlidir. $\mathrm{Bu}$ farklılaşma sosyal ortamlarda üniforma benzeri bir giysi ile karşılanabilirken sanal âlemde bir tür rütbe sistemi ile gerçekleşebilir. Son olarak ise topluluk, üyelerinin hayat görüşlerini daha geniş topluluklarda temsil edilmesine olanak vermelidir. Tüm gereklilikler göz önüne alındığında Pro-Amat aktivitelerinin tek başına gerçekleştirilemeyeceği rahatlıkla söylenebilir. ${ }^{35}$

Daha önce aktarıldığı gibi kitle kaynak yöntemi bağlamında önemli bir diğer topluluk ise üreketicilerdir. Üreketici terimi, ilk defa üretici ile tüketici kelimelerini birleştiren Alvin Toffler tarafından dile getirilmiştir. Yazar, 1980 yılında yayınlanan "Üçüncü Dalga" adındaki kitabında gelecekteki tüketim toplumları üzerinde tahminlerde bulunmuş, bilgi topluluklarını başarıyla tahmin ederek üretici ve tüketicilerin arasındaki sınırların kalkacağını aktarmıştır. ${ }^{36}$

\footnotetext{
${ }^{34}$ Pierre Bourdieu, A Social Critique of Thee Fudgement of Taste, RKP, London, 1985'den aktaran Charles Leadbeater, Paul Miller, The Pro-Am Revolution, Demos, London, 2004, p. 39-40.

${ }^{35}$ Leadbeater, Ibid., p. 44.

${ }^{36}$ Alvin Toffler, Üçüncü Dalga, (çev. Selim Yeniçeri), Koridor Yayıncılık, İstanbul, 2008, s. 17.
} 
Rüzgâr sörfü sporunda 1970'lerin sonunda gerçekleşen değişimler üreketicilerin piyasaya olan etkisini bize göstermektedir. Şöyle ki rüzgâr sörfü sırasında dalgaların yardımıyla havalanmak, popüler bir hareket olarak görülmekteyse de sporcular yükseliş sonrası denize düştüklerinde çoğunlukla dengelerini kaybetmişlerdir.

Bu durum rüzgâr sörfçü Larry Stanly'nin 1970'lerin sonunda sörf tahtasına ayak bağı monte etmesine kadar devam etmiştir. Ayă̆ını sörf tahtasına bağlayan sörfçü ne kadar yükselirse yükselsin tahta ile temasını kaybetmemiştir. Böylelikle en zorlu akrobatik hareketler bile gerçekleştirebilmiştir. Bu icat, rüzgâr sörfü malzemeleri üreten bir şirketten değil bir rüzgâr sörfçüsünden gelmiştir. Kısa süre sonra bu aparatın ne kadar başarılı bir buluş olduğunu keşfeden üretici firmalar, piyasayı ipli rüzgâr sörfleriyle donatmışlardır. Burada gözden kaçırılmaması gereken nokta, rüzgâr sörfü tahtasını kullanan sporcunun, tahtası ile ilgili sahip olduğu problemi herhangi bir üretici firmayı beklemeden, kendisinin çözmesidir. Ancak bu durum şirketlerin aleyhine değildir. Zira kullanıcıların inovasyon yapma kabiliyetini keşfeden bazı firmalar kullanıcı odaklı üretim mekanizmaları üzerine çalışmalar yapmaktadır. ${ }^{37}$

2001 senesinde MIT'de doktora öğrencisi olan Seth Griffin adındaki bir öğrencinin açık kaynağı internet ortamından çıkarıp fiziksel ortama aktarma denemesi de bu konuda dikkate değerdir. Griffith, bu projesinde uçurtma sörfü tahtasını, çoğunluğu uçurtma sörfüyle ilgilenen çevrimiçi bir topluluğun yardımıyla oluşturmaya ve geliştirmeye çalışmıştır. Bunun için bir site kuran Griffith (www.zeroprestige.com), sörf tahtasının nasıl yapılacağ 1 ve geliştirileceğine dair rehberleri ücretsiz olarak kullanıcılara sunmuştur. Bu rehberi indiren kullanıcılar kendi iyileştirmelerini, hatta kendi projelerini topluluğa sunmuştur. Çalışmanın sonunda ise onaylanmış bir rehber ortaya çıkmıs ve indirilebilir olarak kullanıcılara sunulmuştur. ${ }^{38}$

$\mathrm{Bu}$ örneklerden anlaşılacağı üzere Linux ve Apache gibi açık kaynak kodlu yazılımları geliştiren kişiler üreketiciler topluluğu içinde sayılmaktadır. Zira bu kişiler geliştirdikleri ürünün hem üreticisi

\footnotetext{
${ }^{37}$ von Hippel, Ibid., p. 1.

${ }^{38}$ Ibid., p. 103-104.
} 
(geliştireni) hem de tüketicisi konumundadırlar ve açık kaynak ürününe bireysel katkılarda da bulunabilmektedirler. Bunlarla birlikte Pro-Amat'larla üreketicilerin arasına kesin bir sınır koymak çok zordur. Çünkü Linux örneğinden yola çıkacak olursak, profesyonel hayatında bilgisayar odaklı bir iş yapmayan pek çok kişinin amatör olarak kodlamayla ilgilendiği ve Linux gibi açık kaynak kodlu yazılımların geliştirilmesine yardımcı olan internet forumlarına katıldığı bilinmektedir. Görülmektedir ki kitle kaynağın tabanını oluşturan Pro-Amat'lar ve üreketiciler birbirine karşıt gibi görülen kavramların birleştirilmesinden oluşmuştur. Teknolojinin üretici-tüketici ve profesyonel-amatör kavramları arasındaki sınırı silikleştirmesi bir yerde kitle kaynak yöntemini ortaya çıkaran en önemli faktörlerden biridir.

Bunun yanında tanımı kesin olarak yapılamayan ve günümüzün dijital dünyasına mahsus bu tür kavramlar hangi uygulamaların kitle kaynak sayılabileceği konusunda soru işaretlerine yol açmıştır. Bu sebeple kavramın ayırt edici özeliklerinin üzerinde durulması gerekmektedir. Her şeyden önce kitle kaynak sistemleri her ne kadar açık kodlu yazılımlar ve Vikipedi gibi kolektif üretim sistemini kullanan sitelerle aynı temelden hareket etse de bu sistemlerden farklı bir yol izlemektedir. Nitekim kitle kaynak, hiyerarşinin olmadığı ve otoriteye ihtiyaç duymayan bir sistem değildir. Açık kaynak kodlu yazılımlardaki yatay hiyerarşik yapı, kitle kaynakta tam anlamıyla bulunmamaktadır. Şöyle ki bu tür projelerde katılımcıların her biri aslında kendi ajandalarına sahiptir. Bu da demektir ki projeyi başlatan kişilerin, yazılımın hangi yönde ilerleyeceği konusundaki fikirlerinin etkisi yok denecek kadar azdır.

Bunun yanında kitle kaynak yönteminde, kitleyi yönlendiren, gelen verileri işleyen, hedefe ulaşılması için ceza, ödül sistemini uygulayan proje sahipleri görülür. Kitle kaynağın ayırt edilmesinde dikkat edilecek kilit özellikler şunlardır:

- Yapılması gereken görevi üstlenmiş bir yönetim,

- Görevi yerine getirmeyi kabul etmiş bir topluluk,

- Görevin yapılmasına ve organizasyon ile topluluk arasında iletişime olanak sağlayan çevrimiçi bir ortam, 
- Yönetim ve topluluk arasında karşılıklı çıkar ilişkisinin kurulması. ${ }^{39}$

Buradaki en kilit nokta ise gücün, yönetim ve kitle arasında nasıl konumlanacağıdır. Kitle kaynak projesinde tarafların karşılıklı yarar sağlaması için gücün, yönetim ve topluluğun ortasında konumlandırılması gerekmektedir. Bunun nedeni gücün yoğunluklu olarak yönetimde toplanması durumunda topluluğun, bir piyon haline gelmesidir. Öte yandan eğer güç kitlede yoğunlaşırsa topluluk, kendi stratejik hedefleri doğrultusunda hareket edip projenin ilk hedeflerini saptırabilmektedir. ${ }^{40}$

Görüldügü gibi kitlenin varlı̆̆ı bazı zorlukları ortaya çıkarmaktadır. Ancak yine de kitle kaynağın en önemli avantajlarını sağlayan etmen yine kitledir. Nitekim kitle kaynak projelerindeki gönüllülük ilkesi, işin her zaman onu yapmayı en çok isteyenler tarafından yapılmasını sağlamaktadır. Eğer kitle üretimini tercih eden şirket veya kişi zayıf performans gösteren katılımcıları adil şekilde ayıklayacak bir mekanizma yaratabilirlerse, iş için en uygun kişiler geriye kalacaktır. Bu da hiyerarşik yapıdaki kurumların hantal ve çoğu zaman isteksiz elemanlarını geride bırakacakları anlamına gelmektedir. ${ }^{41}$

Bunun yanında kitleyi arkasına alarak proje geliştirmek isteyen kurumlar, kurum içinde istihdam edilmeyen yetenekli kişilerden yararlanma fırsatı da elde etmiş olmaktadırlar. Özellikle kitleyi motive etmek için verimli yollar kullanan şirket ve kişiler bu başarılı katılımcıların katkılarını neredeyse hiçbir maddi karş1lık vermeden sürekli hale getirebilmektedir. Bu yetenekli katılımcıların verimli girdileri projenin ilerlemesine yardımcı olurken fikirler direkt kurumun ürünü haline gelmektedir. Yani kitleyi arkasına almış bir proje, kurumun ihtiyacı olan yeni fikir ve hayat kolaylaştırıcı çözümlerin kolay şekilde süzülmesine yardımcı olmaktadır. ${ }^{42}$

\footnotetext{
${ }^{39}$ Enrique Estellés-Arolas, Fernando González L. Guevara, "Towards an Integrated Crowdsourcing Definition," Fournal of Information Science, Vol. 38, No. 2, 189-200, 2012, p. 10.

${ }^{40}$ Brabham, Ibid., p. 4.

${ }^{41}$ von Hippel, Ibid., p. 68-69.

${ }^{42}$ Topscott, Ibid., p. 93-94.
} 


\section{Ushahidi Platformu}

Kitleyi arkasına alma işlemini en başarılı şekilde yapan kitle kaynak projelerinden biri olan Ushahidi, Google Haritalar'a bağlı bir e-posta hesabı olarak tasarlanmıştır. Bunun yanında platform, e-postalarla beraber tweet ve kısa mesajları da alabilmektedir. Örneğin Haiti'deki deprem sonrası Ushahidi uygulamasını başlatan kişilerden biri olan Patrick Meier, platformdaki posta kutusunu "Haiti" ve "deprem" kelimelerini içeren tüm tweetleri toplayacak şekilde ayarlamış, sonuçta elde edilen tweetler burada birikmiştir. Daha sonra, bu tweetlerdeki metni kopyalayıp haritaya eklemiş ve kısa sürede bilgiler görselleştirilmeye başlanmıştır. ${ }^{43}$

Ushahidi, Swahili dilinde "tanıklık" anlamına gelmektedir. Platform ilk olarak 2007-2008 yıllarında Kenya'da yaşanan şiddet olayları sırasında kullanılmaya başlanmıştır. Bu olayların nedeni ise 2007 yılında ülkede yapılan başkanlık seçimlerine hile karıştırıldığı iddiasıdır. Şöyle ki adaylardan biri olan Mwai Kibaki, rakibi Raila Odinga'nın ve destekçilerinin seçimlerde hile yapıldığı suçlamalarına karşın zaferini ilan etmiş ve bunun sonucunda özellikle ülkenin merkezden uzak bölgelerinde etnik temelli şiddet eylemleri meydana gelmiştir. Çatışmaların kırsal alanlarda yaşanması, ulusal ve uluslararası medyanın bölgeden bilgi aktarımı yapmasını zorlaştırmış, bu da alternatif yolların aranmasını zorunlu hale getirmiştir. Platformun kurucularından biri olan Avukat Ory Okhollo, Ushahidi'nin kurulmasına giden süreci nelerin başlattığını şu şekilde açıklamıştır:

"Hükümet, polis ve medya tarafindan bildirilen ölümlerin gerçek sayıdan daha az rapor edildiğine inanıyoruz. Ayrca, gerçekten neler olup bittiğine dair sağllkh bir tabloya sahip olduğuтиzu da düşünmüyoruz, etkilenen bölgelerdeki ailelerden ve arkadaşlarımıdan duyduğumuz her şey, durumun medyada duyduğumuzdan çok daha kötü olduğunu gösteriyor. Ayrıca (idealist dünyamda), bu karmaşa içinde hayatın kaybeden insanlara birer isim ve yüz verebilmeyi umuyoruz. Peki, tüm bunlar ne için? Kenyalılar yaşanan kötü olaylar çok çabuk unuttuğunu tekrar tekrar gösterdi. Bu kriz sona erdiğinde, "hayatın devam etmesi" adına yaşanan tüm olaylarn halının altına süpürülmesini istemiyoruz, gerçekten

${ }^{43}$ Patrick Meier, Digital Humanitarians, CRC Press, New York, 2015, p. 2. 
hayata devam etmemiz için, gerçeklerin söylenmesi gerekiyor. Ushahidi buna katkıda bulunmanın küçük bir yolu. ${ }^{~} 4$

Buradan hareketle platformun ana amacinın yurttaşlara seçim sonrası tanık oldukları şiddet olaylarını mobil telefonlarını kullanarak haber verme olanağı sağlamak, çatışmaları tarihleriyle birlikte arşivlemek ve Kenya kamuoyuna şiddet eylemleri ile ilgili sağlıklı bilgiler ulaştırmak olduğu söylenebilir. ${ }^{45}$

\section{Resim 1: Ushahidi platformunun yayına geçtiği 2007-2008 yıllarındaki görünümü}

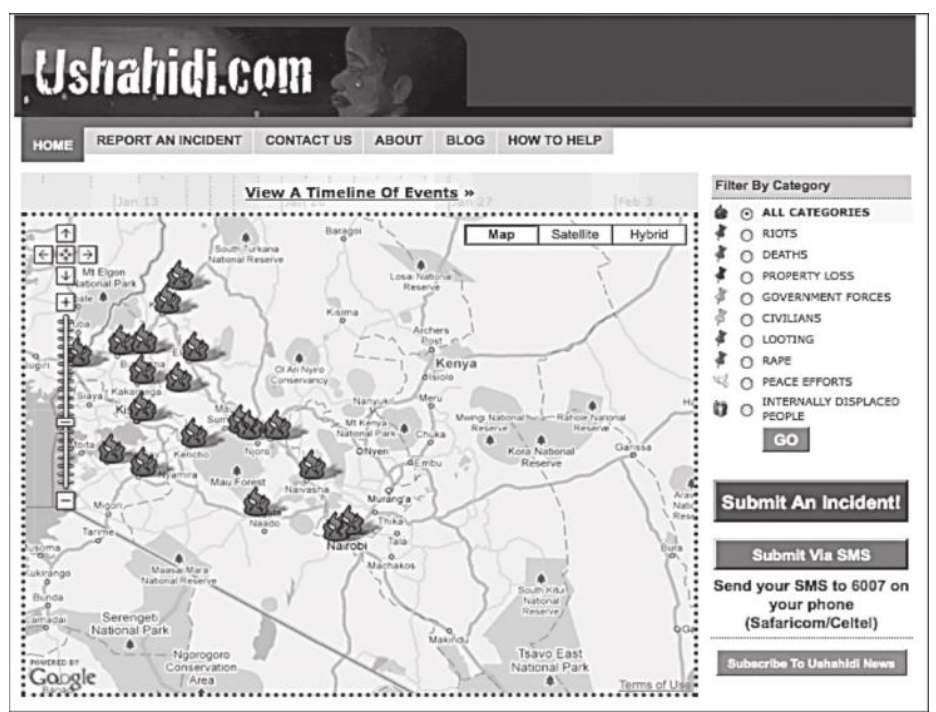

Kaynak: Jessica Heinzelman, Carol Waters, "Crowdsourcing Crisis Information in Disaster Affected Haiti, United States Institute of Peace”, 2010, s. 5 , https://mirror.explodie.org/Crowdsourcing\%Crisis\%20Information\%20In20Informatio n\%20Disaster-Affected\%20Haiti.pdf, (Erişim Tarihi: 20.03.2020).

${ }^{44}$ Simon Jeffrey, "Ushahidi: crowdmapping collective that exposed Kenyan election killings", https:/www.theguardian.com/news/blog/2011/apr/07/ushahidi-crowdmap-kenya-violencehague, (Erişim Tarihi: 14.03.2020).

${ }_{45}$ Jessica Heinzelman, Carol Waters, "Crowdsourcing Crisis Information in Disaster Affected Haiti, United States Institute of Peace”, 2010, s. 3-4, https://mirror.explodie.org/ Crowdsourcing\%Crisis\%20Information\%20in\%20Disaster-Affected\%20Haiti.pdf, (Erişim Tarihi: 20.03.2020). 
Ushahidi, Kenyalı gazetecilere detaylı görgü tanığı raporlarını ve coğrafi koordinatları zaman yelpazesi ile birlikte aktarma şansı vermiştir. $\mathrm{Bu}$ durum, kullanılan kitle kaynak yöntemi sayesinde detaylı bir harita oluşturulmasına olanak sağlamıştır. Öte yandan geleneksel yöntemleri kullanan ana akım medya ise birçok bakımdan dezavantajlı durumda kalmıştır. Bu dezavantajlar ve ortaya çıkardıkları sonuçlar şunlardır:

- Görgü tanıkları tarafından iletilen şiddet haberleri Ushahidi'ye hızlı ve pratik bir şekilde aktarılırken, ana akım medyanın haber kaynakları herhangi bir bilgiyi doğrulayamamıştır.

- Ushahidi'nin yaşanan olayları haber verdiği bölge ana akım medyanın haber verebildiğinden çok daha geniş ve çeşitli olmuştur.

- Platform, sayıca daha fazla şiddet olayı raporlamış, geleneksel yollarla ortaya çıkarılamayan birçok şiddet eylemi raporlamıştır. ${ }^{46}$

Bu avantajlardan dolayı Ushahidi platformu kısa bir süre sonra pek çok farklı amaç için kullanılmaya başlamıştır. Örneğin "HarassMap" adındaki bir kuruluş, 2010 yılında Mısır, Kahire’de kadınların tacize uğradığı yerleri kitle kaynak yöntemi ile tespit etmeye çalışmış, alınan verileri Ushahidi'nin platformu ile görselleştirmiştir. 2011 yılında Libya'da başlayan şiddet olayları hakkındaki bilgiler de yine Ushahidi platformunda kendine yer bulan bir başka gelişmedir. ${ }^{47}$

\subsection{Ushahidi'nin Haiti'deki Deprem Felaketi Sonrası Kullanımı}

Söz konusu deprem, 12 Ocak 2010 tarihinde gerçekleşmiş, büyüklüğü ise 7,0 olarak ölçülmüştür. Merkez üssü, başkent Port-au-Prince'in $25 \mathrm{~km}$ batısında olan Léogâne şehridir. Deprem, özellikle ülkenin büyük şehirlerinde büyük bir hasara yol açmıştır. Öyle ki Léogâne kentindeki binaların en az yüzde 80 'i yıkılmış, başkent ve çevresindeki yerleşim yerlerinde on binlerce bina da bu felaketten etkilenmiştir. Hasar gören binalara Birleşmiş Milletler genel merkezi, başkanlık sarayı, parlamento binası ve çeşitli bakanlıklara ait 29 adet yapı da dâhildir. Deprem sonucu Haiti hükümetine göre 222 bin kişi ölmüş, 300 bin kişi yaralanmıştır. Ölenlerin arasında BM'nin barış gücü görevinin başındaki personelle birlikte

\footnotetext{
${ }^{46}$ A.g.r., s. 5.

47 “10 Years of Impact”, Ushahidi, 2018, s. 32, 40, https://www.ushahidi.com/uploads/ case- studies/Impactport2018.pdf, (Erişim Tarihi: 20.03.2020).
} 
$96 \mathrm{BM}$ çalışanı, 80 Haiti polisi ve 31 yerel gazeteci de vardır. Uluslararası organizasyonlar yaşanan yıkım sonrası bölgede yaşananları, Ushahidi platformuyla öğrenmişlerdir. Platform, Twitter, Facebook ve internet blogları gibi paylaşım sitelerinden edinilen bilgileri, kitle kaynak yöntemi ile mobil telefonlardan kendilerine iletilen bilgilerle birleştirip, bunları internete erişimi olan herkese interaktif bir harita aracılığıyla aktarmıştır. ${ }^{48}$

Tüm bunlarla beraber platformun ne kadar kullanışlı olduğu siyasilerin ve analizcilerin gözünden kaçmamıştır. Örneğin dönemin ABD Dışişleri Bakanı olan Hillary Clinton, 21 Ocak 2010 tarihindeki "İnternet Özgürlügü̈” konuşmasında teknolojinin yetkililere nasıl yardım edebildiğini: "Teknolojiyi kullanan kitleler interaktif haritalar yaratarak, insanların ihtiyaçlarını ve hangi kaynakların gerekli olduğunu bize anlatmaktadır... Pazartesi günü Amerikan arama ve kurtarma ekibi kendilerine mesaj atan yedi yaşındaki bir kız çocuğunu ve iki kadını yıkılan bir süper marketin altından kurtarmıştır" diyerek açıklamıştır. ${ }^{49}$

Öte yandan Ushahidi sitesi uluslararası alanda çalışmalar yapmak isteyen analizcilere de veri kaynağı olmaktadır. ABD Deniz Piyade Kolordusu'nda açık kaynak istihbarat analizcisi olan Craig Clarke'ın bu konuda düşünceleri şu şekildedir:

"Modern çağda artık açık kaynak istihbaratı geleneksel istihbarat yöntemlerinden daha verimli hale gelmiştir... Kriz haritacılĭg kavramı açık kaynak istihbaratınn üstün özelliklerini göstermektedir... Haiti depreminden sonra Ushahidi'nin raporlarn geleneksel istihbarat yöntemlerine göre kesin bir şekilde daha verimli olmustur." 50

Geleneksel istihbarat alma yollarının ne derecede verimsiz olduğu felaketi takip eden ilk 10 günde belli olmuştur. Deprem sonrasında geleneksel yolları izlemeyi tercih eden BM, bu konuda üzerinde durulması gereken bir kurumdur. Öncelikle BM'nin ülkedeki krize cevap verme sistemleri ülke içindeki kanaat liderlerinin oluşturduğu istihbarat ağıla yeterince entegre

\footnotetext{
${ }^{48}$ Heinzelman, a.g.r., s. 2.

${ }^{49}$ Hillary Rodham Clinton, "Remarks on Internet Freedom", https://20092017.state.gov/secretary/20092013 clinton/rm/2010/01/135519.htm, (14.03.2020).

${ }^{50}$ Heinzelman, a.g.r., s. 2.
} 
olamamıştır. BM bunun yerine haberleşme ağlarını uluslararası kuruluşlar arasında kurmaya yoğunlaşmıştır.

$\mathrm{Bu}$ hata kendini ilk defa BM'ye gelen telefon aramaları, e-postalar ve mektuplarla belli etmeye başlamıştır. Nitekim yardım çağrılarına bir yanıt alamayan kanaat önderleri kurumun karar alıcılarından bilgi almak ve onlara haber vermek için BM Lojistik Merkezi'ne gitmişlerdir. Ancak uluslararası cevap sisteminin böylesi girdileri işleyebilecek bir mekanizmadan yoksun olması, Haitililerle, kriz müdahale kuruluşlarının iletişimini engellemiştir.

İletişimde yaşanan bu aksamalar sonucu sistem, yardım taleplerini karşılayamaz duruma gelmiştir. Nitekim bu tür durumlarda yapılması gereken en önemli işlerden biri, gelen talepleri doğrulamak ve bunları önemine göre sıralayarak durumu kritik olan afetzedelere öncelik vermektir. Ancak BM'nin oluşturduğu istihbarat ağının yetersizliği bölgeden haber almayı ve bunları doğrulamayı zorlaştırmış, bu da afetzedelerin durumlarının aciliyetine göre sıralanmasını imkânsız hale getirmiştir.

Öte yandan uluslararası medyanın, felaketi haberleştirme şekilleri de sahadaki yardım çalışmalarına zarar vermiştir. Felaket bölgesinden sağlıklı bilgilerin alınamaması özellikle internet medyasında bazı sansasyonel haberlerin dağıtıma çıkmasıyla sonuçlanmıştır. Örneğin Port-au-Prince şehrinde yaşanan küçük çaplı şiddet olayları, medyada abartılı bir şekilde gündeme getirilince bölgeye intikal eden yardım ekipleri kendi güvenlikleri için söz konusu haberleri teyit ettirmeye çalışmıştır. Bu işlem zaman aldığından acil yardıma ihtiyacı olan insanlar mağdur olmuşlardır. Bu vaziyet zincirleme etki yaratmıs ve yardımın geciktiği bölgelerdeki şiddet içerikli eylemler dikkat çekici şekilde yükselmiştir. Sonuç olarak yaşanan bu zorluklar yeni bir istihbarat yöntemine olan ihtiyacın altını çizmiştir. İşte bu ihtiyaca Ushahidi platformu cevap verebilmiştir. ${ }^{51}$

Ushahidi, Kenya'daki olaylardan sonraki birçok toplumsal olayda kullanılmış ve verimliliğini tekrar tekrar kanıtlamış olsa da Haiti'de gerçekleşen deprem felaketi, platformun uluslararası tanınırlığına en çok katkıda bulunan olaylardan biri olmuştur. Ushahidi, 12 Ocak'1 takip eden ilk birkaç saat içerisinde aktifleşmiştir. Ancak haritanın açılmasıyla

${ }^{51}$ A.g.r., s. 3. 
Ushahidi'nin teknik ekibi ortalıkta dolaşan yüksek miktardaki bilgilerin bu küçük ekip tarafından işlenmesinin mümkün olmadığını fark etmiş, bunun için ABD'deki Tufts Üniversitesi, Fletcher Hukuk ve Diplomasi Okulundaki gönüllülerden oluşan bir ekipten yardım istemiştir.

Birlikte çalışan ekip sosyal medya sitelerini, blogları ve geleneksel medyayı tarayıp önemli verileri işlemeye başlamıştır. Haber değeri olduğu düşünülen olaylar, eğer gerçekleştiği yer ile birlikte verilmişse, koordinatları GoogleEarth ve OpenStreetMap gibi platformlardan bulunup, haiti.ushahidi.com adresindeki haritaya aktarılmıştır. Bunun yanında platform, en değerli bilgileri birincil kaynaklar olan felaket bölgesinde bulunanlardan almıştır. İnsanlar en başından itibaren e-postalar ve doldurulması istenen formlar aracılığıyla teknik ekibe veri aktarmaları için teşvik edilmiştir.

Veri akışı için yapılan en önemli adımlardan biri ise bölgedeki insanların Ushahidi ekibine bilgi aktarması için kurulan SMS sistemidir. $\mathrm{Bu}$ sistem, Fletcher'daki gönüllüler ekibi ile FrontlineSMS, ABD'nin Dışişleri Bakanlığı ve Digicel ortaklığı ile geliştirilmiştir. Amaç; afet bölgesinde bulunan kişilerin, önemli olduğunu düşündükleri ve ekibe göndermek istedikleri bilgileri, 4636'ya kisa mesaj atarak Ushahidi ekibine gönderebilmelerini sağlamaktır. Böylelikle elde edilen bu bilgiler Ushahidi'nin Haiti haritasına aktarılabilecektir. ${ }^{52}$

SMS sisteminin verimli olacağının düşünülmesinin en büyük sebebi depremin olduğu zaman Haiti'deki hanelerin yüzde 85'inin mobil cep telefonuna sahip olmasıdır. Port-au-Prince'deki telefon kulelerinin yüzde 70’i depremle yıkılsa da SMS sistemi devreye sokulmadan önce tümü tamir edilebilmiştir. 4636 sistemi gerçekten de Haitililerin doğrudan iletişim kurabildikleri yegâne kanal olmuştur. Hatta bu hat çoğu kişi için "hayatta kalanlar için bir yaşam hattı" olarak tanımlanmıştır. Elektriğin olmaması cep telefonlarının kullanılmasını engellememiş, afetzedeler benzin istasyonlarındaki bataryaları kullanarak telefonlarını şarj etmeyi başarmışlardır. ${ }^{53}$

\footnotetext{
${ }^{52}$ A.g.r., s. 6-7.

53 Pascal Fletcher, "Post-Quake Recovery May Boost Haiti Telecoms Market", https://www.reuters.com/article//idUSN30159947, (Erişim Tarihi: 08.02.2020).
} 
Böylelikle 4346 projesi Haitililerle yardım ekipleri arasında dolaylı bir iletişim aracı olmuştur. Fletcher'daki gönüllü ekip, kendilerine gelen bilgileri harita üzerinde görselleştirerek her türden yardım operasyonuna yön vermiştir. Sistem ilk başta FrontlineSMS'den Josh Nesbit tarafindan Twitter'dan duyurulmuştur. Burada ilgi çekici olan nokta, projenin Haiti'de teknolojik olmayan yollardan da yayılmaya çalışıldığıdır. Örneğin deprem bölgelerinde posterler asılmış ve ağızdan ağıza iletişim yolu kullanılarak insanlara haber verilmeye çalışılmıştır. Bunun üzerine ekip, bölgeden birçok mesaj almaya başlamıştır.

Bunun yanında ortaya çıkan sorunlardan biri günde 1000 ile 2000 arasında gelmeye başlayan mesajların, Haiti dilinden İngilizceye çevrilmesi problemi olmuştur. Bunun için Stanford Üniversitesinden Rob Munro, Ushahidi sitesinin yöneticilerinden Brian Herbert ile Mission4636 adında web tabanlı bir proje başlatmıştır. Bu projede ABD ve Kanada'da yaşayan binin üzerindeki Haitili, ekibe gelen mesajları İngilizce'ye çevirmiş ve coğrafi koordinatlarıyla beraber sisteme yüklemiştir. Munro'nun aktardığına göre mesajın Mission4636 sistemine düşmesiyle, Ushahidi ekibine gitmesi 10 dakika sürmüştür. ${ }^{54}$

Gelen mesajların ihtiva ettiği bilgiler ise genelde insanları yardım merkezlerine yönlendirmek ve yardım ekiplerini ihtiyaç duyulan yerlere sevk ettirebilmek için gereken enformasyonlar olmuştur. Bunların arasında yiyeceklerin bulunduğu yerler, yardım merkezleri, hatta yakıt olan ve telefon şarj edebilecekleri yerlerin bilgileri de vardır. Tüm bu enformasyonlar, Ushahidi'nin açtığı haritaya yüklenerek, afetzedelerin bundan istifade etmesi sağlanmıştır.

Dil sorununun yanında gelen bilgilerin doğruluğunu teyit ettirmek de bazı işlemler gerektirmiştir. Bunun için mesajlar çevrildikten sonra Ushahidi-Haiti platformuna gönderilmiş, daha sonra burada 100 kişilik bir öğrenci grubu tarafından incelenip uygun bir forma sokulduktan sonra onaylanmıştır. Acil olarak görülen bilgiler ise önemli olarak etiketlenmiştir ve Fletcher'daki ekip tarafından önemine göre sıralanmıştır. Burasının

\footnotetext{
${ }^{54}$ Heinzelman, a.g.r., s. 7.
} 
ABD'nin sahil güvenlik birimleriyle doğrudan bir hatta sahip olması ekibin işlerini kolaylaştırmıştır.

Buradaki ekip, acil olarak görülen mesajlarda koordinat yoksunluğu gibi bilgi eksikleriyle karşılaştığında ise raporu ileten kişi ile Ushahidi platformunun sağladığı "cevap gönder” fonksiyonuyla iletişime geçerek bilgi boşluğunu doldurmaya çalışmıştır. Örneğin ekip, bir defasında Wayal Üniversitesinin, Royal Üniversitesi ile aynı olup olmadığını kontrol etmek için platformun bu özelliğini kullanmıştır. Projede, gelen tüm bilgiler bu şekilde netleştirip doğrulama şansına erişilemese de platformun sunduğu bu özellikle, afetten en çok etkilenmiş kişilere ulaşılıp önemli bilgilerin teyit ettirilmesi sağlanabilmiştir.

Öte yandan 4346 projesinin üstlendiği en meşakkatli işlerden biri de raporların gerçek zamanlı olarak haritalanması işi olmuştur. Deprem bölgesinin ayrıntılı bir haritası olmaması yanında en büyük sorun, deprem sonrası üretilen hiçbir haritanın olmamasıdır. Burada sorun yine teknolojiyle çözülmüş, bunun için gönüllülerden oluşan yeni bir ekip kurulmuştur. Bu ekip harita oluşturulmasına olanak veren ve haritaların Vikipedi'si olarak da bilinen OpenStreetMap sitesi üzerinde çalışmıştır. OSM sitesini daha önce farklı amaçta kullanmış kişilerden oluşan bu ekip, deprem sonrası bulabildikleri her bilgi parçasını kullanarak harita oluşturmaya başlamıştır.

Gönüllüler, eski Yahooo haritalarını ve müşterilerine uydudan çekilmiş haritalar sağlayan bir şirket olan DigitalGlobe'un kendilerine bağışladığı haritayı (ABD bu iş için harita üzerindeki gizlilik ibaresini kaldırmıştır) kullanmışlardır. Bunlara ek olarak DijitalGlobe ile aynı işi yapan GeoEye da uydu görüntülerini bu ekibe bağışlamayı kabul etmiştir. $\mathrm{Bu}$ haritalandırma işleminden büyük verim alan ekip, kısa bir süre sonra Google Maps haritasının üzerinde çalışmayı bırakıp, OSM'deki haritayı kullanmaya başlamıştır.

Projenin diğer bir önemli yanı ise şu ana kadar yapılan tüm bu meşakkatli ve teknik işlerin gönüllüler tarafından yerine getirildiği gerçeğidir. Daha önce medya ve diğer alanlarda yapılan kitle kaynak projelerindeki yönetici, yani kümeleyici rolü üstlenen organizasyon, Ushahidi'nin Haiti uygulamasında tamamen gönüllerden oluşmaktadır. Öte yandan bu grup kitle kaynağı sadece afet bölgesindeki insanlardan bilgi almak için kullanmamıs, dünyanın her yerinden çeşitli uzmanlık 
alanlarına sahip kişi ve grupları da girişimin ihtiyaçlarına göre (yine gönüllülük esasıyla) organize etmiştir. ${ }^{55}$

\subsection{Ushahidi'de Toplanan İstihbaraten Mahiyeti}

4346 projesi çalışanları 25 bin 186 SMS'i, sayısız e-posta ve web/sosyal medyadaki bilgileri çevirmiş, sonuç olarak 3596 adet raporu Ushahidi'nin haritalama projesinde kullanılmak üzere hazırlamıştır. Bu raporların büyük bir çoğunluğu "hayati hatlar" olarak kategorize edilmiş olup, yiyecek, su ve barınma ile ilgili talepler ihtiva etmektedir. İkinci en çok raporlanan bilgiler ise afet sonrası halen çalışan servislerle ilgilidir. Bunlara sahra hastanelerin konumlarının yanında, oldukları yerde sıkışmıs afetzedeler ve acil müdahale isteyen diğer önemli olaylar hakkındaki bilgiler de dâhildir. ${ }^{56}$ Yardım isteyen kişilerin gönderdiği iletilerin bazıları şu şekildedir:

"Adım [gizlilik nedeniyle kaldrrldi] hayattayım. [Adres gizlilik nedeniyle kaldırldı] olan Caraibes Üniversitesi'nde molozlarn altındayım. Lütfen gelin ve alın beni."

"Benim adım [gizlilik nedeniyle kaldırldı] kardeşim Unicef'te çalışıyor ve [adres gizlilik için kaldırldı] yaşıyor. Hala bina altında hayatta olan 2 kişi var! Yardım gönderin!" 57

Ushahidi'nin ürettiği bu 3596 raporun sadece 54 tanesi, yani yalnızca yüzde 1,5 'i şiddet ve güvenlik kategorisindedir. Bu durum, afetin ilk gününden itibaren bölgede gerçekleşen şiddet olayları ile ilgili abartılı ve sansasyonel haberler yapan ana akım medya göz önüne alındı̆̆ında daha anlamlı olmaktadır. Bunun yanında Ushahidi ekibinin şiddet olaylarını içeren bilgilerin tümünü teyit edememesi ve sahada yaşanan olayların tümünün rapor edilmesinin imkânsız olduğu da göz önüne alınarak, afet sonrası yaşanan şiddet olaylarının yoğunluğu hakkında, bütüncül bir bilgiye sahip olunamadığının altı çizilmelidir.

Ushahidi'nin Haiti'de ortaya koyduğu performans afet sonrası birçok hayatı kurtarmış ve tüm dünyaya haberi üretiminin yeni bir versiyonunu göstermiştir. Bu durum, Ushahidi'nin kullandı̆̆ kriz haritalama yönteminin

\footnotetext{
${ }^{55}$ A.g.r., s. 8

${ }^{56}$ A.g.r., s. 9.

${ }^{57}$ Meier, Ibid., p. 10.
} 
afet sonrasında da yeni amaçlarla kullanılmasını sağlamıştır. Örneğin Solution adındaki Haiti merkezli bir yazılım şirketi tarafından hayat geçirilen Noula.ht şirketi bunlardan biridir. Şirket geliştirdikleri bu projeyi Haiti hükümetiyle ortaklaşa yürütmüş ve Ushahidi'de olduğu gibi kitle kaynak yöntemini bu sefer bölgenin aldığı hasarın iyileştirilmesi için kullanmıştır. ${ }^{58}$

\subsection{Ushahidi'nin Başarnlı ve Başarısız Olduğu Alanlar}

Ushahidi ve onun Haiti depremi sonrasındaki kullanımı bize bazı önemli dersler vermiştir. Bunların en önemlilerinden biri Ushahidi'nin bir kitle yaratabilmesi ve motivasyonu yüksek tutabilmesidir. Öyle ki platforma gelen SMS'leri İngilizceye çevirmek için sadece ilk hafta 50 bin kişi çeşitli sohbet platformlarında birbirleriyle iletişime geçmiştir. Gerek Boston'daki ekip gerekse de projenin etrafında toplanan kitlenin en büyük moral kaynakları; bir cemiyete ait olma ve birilerine yardım etme güdüsüdür. En verimli çevirmenlerden olan bir katılımcı bu konuda şöyle söylemektedir:

"Haitili insanlara yardlm eden bu kadar çok farkl arka planl, kültürlü ve değişik ülkeden kişinin olması mükemmel. Burada muhteşem insanlarla tanıştım... Insanlar burada Kreolce mesajlarn çevirmek için sabahtan akşama kadar saatlerini harcıyor ve Haiti haritasın güncelliyor. Onlarn özverileri, özenleri ve iyi kalplilikleri beni daha çok çalışmaya teşvik ediyor. "\$9

Buradan yola çıkılarak gerekli altyapı sağlandığı takdirde, insanların zor durumdaki kişilere yardım etmekte istekli davrandığ sonucuna ulaşılabilir. Söz konusu altyapı, pahalı ya da ulaşılmaz olmaktan uzaktır. Ucuz ve kolayca şekillendirilebilecek araçlar (Ushahidi platformu gibi) yeterli olmaktadır. Haiti örneğinde cep telefonlarının yeterli olması bu durumu kanıtlar niteliktedir. Ushahidi gibi insani yardım amacıyla kullanılan platformların kullandığı tekniklerin, kısa sürede tüm dünyaya yayıldığı ve taklit edildiği gerçeği bu noktada dikkat edilmesi gereken başka bir noktadır. ${ }^{60}$

Ushahidi uygulaması bu şekilde insani yardım kavramının niteliğini değiştirmiştir. Patrick Meier bu konuda şunları kaydetmiştir:

\footnotetext{
${ }^{58}$ Heinzelman, a.g.r., s. 10.

${ }^{59}$ Patrick Meier, Rob Munro, "The Unprecedented Role of SMS in Disaster Response: Learning from Haiti”, SAIS Review, Vol. 30, No. 2, 90-103, 2010, p. 94.

${ }^{60}$ Clay Shirky, Cognitive Surplus, The Penguin Press, London, 2011, p. 12.
} 
“CNN, Haiti depremiyle ilgili haberler yapmaya başlayınca diğer birçok kişi gibi kendimi tamamen gücssüz ve bunalmış hissettim. Ancak bugün bu duyguları çevrimiçi kolektif eyleme dönüşürme imkânımı var. Gerçekten de artık yapacă̆ımı yardımlar para ile sınırl kalmak zorunda değil, otobüste yolculuk yaparken bile kurtarma çalısmalarna yardım edebiliriz. Ihtiyacinı olan tek şey internet erişimi. Bir Facebook durum güncellemesinde "Beğen"e tıklayabiliyorsanı, dijital ortamda insanlara yardımcı olabilir, anlamlı bir fark yaratabilirsiniz." 61

Bununla beraber Ushahidi, bu özverili çalışma sayesinde bölgenin haritasını başarıyla çıkartabilmiştir. Nitekim Felaket sonrası harita yapımı epey meşakkatli bir iştir. Dünyanın neresinde olursa olsun büyük ölçekli gerçekleşen afetler sonrasında bölgenin haritası değişmektedir. Bunun nedeni köprülerin ve binaların yıkılması ve yolların kapanmasıdır. $\mathrm{Bu}$ sebeple alınan hasarın ölçümü ve planlanan insani müdahaleler için mutlaka güncel bir haritalandırma çalışması yapılmalıdır. İşte Ushahidi’nin Haiti'de üstlendiği görevlerden biri bu olmuş, gerek kitle kaynak yöntemi ile gerekse de açık kaynaklardan aldığı bilgilerle ortaya çıkan yeni durumu başarılı şekilde yansıtabilmiştir.

Alınan bir diğer önemli ders ise Ushahidi'nin kitle kaynak yöntemi ile aldığ 1 istihbaratın teyit edilmesinin meşakkatli bir işlem olduğunun anlaşılmasıdır. Öyle ki Ushahidi-Haiti kriz haritasında kullanılan 3500 mesajdan sadece 202 tanesi "teyit edildi" olarak etiketlenebilmiştir. Kendilerine ulaşan istihbaratın tümünü doğrulamaya vakti olmayan 4346 ekibi, çoğu zaman doğru mesajların yanlış mesajlardan fazla olacağını ummuştur. ${ }^{62}$ Ancak bu durum Ushahidi'nin teyit yönünden verimsiz olduğu anlamına gelmemektedir. Nitekim girişim, Haiti'de sağlam bir teyit mekanizması geliştiremese bile diğer kurtarma çalışmaları ve ekipleri için çapraz bir doğrulama kanalı teşkil etmiştir.

\section{Sonuç}

Bu bilgiler 1şığında kitle kaynak yönteminin istihbarat örgütlerinin organizasyon yapısına ve istihbarat alma şekline yeni yaklaşımlar getirdiği

\footnotetext{
${ }^{61}$ Meier, Digital Humanitarians, Ibid., p. 17-18.

${ }^{62}$ Heinzelman, a.g.r., s. 11.
} 
düşünülmektedir. Bunlar; kitle kaynağın kavramsal çerçevesini oluşturan kitlelerin bilgeliği fikrinin istihbarat örgütlerinin örgütlenme şekillerinde kullanılması ve Ushahidi'nin kullandığı yeni istihbarat alma metodunu temel almaktadır. Öncelikle kitlelerin bilgeliği fikri, devletin, bir kurumlar kitlesinden oluştuğu gerçeğinden yola çıkıldığında önem kazanmaktadır. ABD'nin 11 Eylül saldırıları sonrası yaptığı reformlar bir bakıma devletin istihbarat üreten örgütlerinin kitlelerin bilgeliği fikri ile uyumlu hale getirilmesinden başka bir şey değildir. Nitekim ABD’li yetkililer, 11 Eylül saldırıları sonrası yazılan raporda, yaşanan sorunun istihbarat alınamamasından değil, elde olan bilgilerin toplanarak anlamlı ve isabetli bir analiz yapılamamasından kaynaklandığını belirtmişlerdir. Yani istihbarat kurumları noktaları birleştirip büyük resmi görememişlerdir. $\mathrm{Bu}$ da kitlelerin bilgeliği fikrinin kümeleme şartına işaret etmektedir. Buradan yola çıkarak tüm devlet kurumlarını içerisine alıp, bu kurumların fikirlerinde bağımsız olmasını garanti altına alan ve üretilen tüm raporları merkezî bir örgüt marifetiyle kümelenmesini sağlayan bir istihbarat sisteminin günümüz koşullarına uygun olacağı düşünülmektedir.

Öte yandan Ushahidi platformunun iç çatışma ve felaket olaylarında gösterdiği performans bu yöntemin istihbarat örgütlerince nasıl kullanılabileceğine dair önemli bir örnek oluşturmaktadır. Bu uygulamalarda görüldüğü gibi sivil bir girişim olan bu platform, devlet kurumlarının dahi ötesine geçmiş ve gerçekleşen kritik olaylarda resmî kurumların ana istihbarat kaynaklarından biri olarak değerlendirilmiştir. $\mathrm{Bu}$ minvalde istihbarat kurumlarının belli yöntem ve tekniklerle, dolaylı ya da dolaysiz olarak bu türden bir girişim yürütmesinin ya da sivil girişimleri destekleyip bünyesine almasının yararlı olacağı düşünülmektedir. Burada özellikle bilgisayımsal teknikler ve kitle yönetimi önem kazanmaktadır. İstihbarat kurumlarının dolaylı ya da doğrudan bir şekilde kitle ile gireceği etkileşim, istihbarat analizcilerinin özelinde tüm istihbarat kurumları için yeni bir katılım alanı olarak değerlendirilmektedir.

\section{Summary}

In the light of this information, it is thought that the crowdsourcing method brings new approaches to the organizational structure of intelligence organizations and the way they receive intelligence. It is based on the use of 
the idea of the wisdom of the crowds, which constitutes the conceptual framework of crowdsourcing, in the organizational forms of intelligence organizations and the new intelligence method Ushahidi uses. First of all, the idea of the wisdom of the crowd gains importance from the fact that the state consists of a crowd of institutions. In a way, the reforms made by the US after the 9/11 attacks are nothing but the alignment of the state's intelligenceproducing organizations with the idea of the wisdom of the crowds. In fact, in the report written after the 9/11 attacks, US officials stated that the problem was not due to the lack of intelligence, but to the inability to collect the available information and make a meaningful and accurate analysis. In other words, intelligence agencies could not connect the dots and see the big picture. This points to the clustering principle of the idea of the wisdom of the crowds. From this point of view, it is thought that an intelligence system that includes all state institutions, ensures that these institutions are independent in their opinions, and ensures that all reports produced are clustered by a central organization will be suitable for today's conditions.

On the other hand, the performance of the Ushahidi platform in internal conflict and disaster events is an important example of how this method can be used by intelligence organizations. As seen in these applications, this platform, which is a civilian initiative, has gone beyond even state institutions and has been considered as one of the main intelligence sources of official institutions in critical events. In this respect, it is thought that it would be beneficial for intelligence agencies to carry out such an initiative, directly or indirectly, with certain methods and techniques, or to support and incorporate civilian initiatives. Here, especially computational techniques and crowd management gain importance. The interaction of intelligence agencies with the crowd, either directly or indirectly, is considered a new field of participation for all intelligence agencies, in particular for intelligence analysts.

\section{Çatışma Beyanı:}

Bu çalışmada Prof. Dr. Meltem BOSTANCI ile aramda finansal ve fikirsel bir çatışma yoktur. Bunun yanında makale, kendi çalışmamdır. 


\section{KAYNAKÇA}

\section{Kitaplar}

BOURDIEU, Pierre. A Social Critique of Thee Fudgement of Taste. RKP, London. 1985'den aktaran: Leadbeater, Charles, Paul Miller. The Pro-Am Revolution. Demos. London, 2004.

BRABHAM, Daren C. Crowdsourcing. The MIT Press. Massachusetts. 2013.

HOWE, Jeff. Crowdsourcing. çev. Günseli Aksoy. KoçSistem Bilgi ve İletişim Hizmetleri İstanbul. 2010.

LEADBEATER, Charles. Paul Miller. The Pro-Am Revolution. Demos. London. 2004. MEIER, Patrick, Digital Humanitarians. New York. CRC Press. 2015. SHIRKY, Clay. Cognitive Surplus, The Penguin Press. London, 2011. - Here Comes Everybody, The Penguin Press. London. 2008.

SONNTAG, Sherry, Christopher Drew, Blind Man's Bluff, Public Affairs. New York. 1998'den aktaran: Surowiecki, James. Kitlelerin Bilgeliği. Varlık Yayınları, İstanbul. 2007. SUROWIECKI, James. Kitlelerin Bilgeliği. çev. Osman Deniztekin. Varlık Yayınları. İstanbul. 2007.

TAPSCOTT, Don. Anthony D. Williams. Wikinomics. Penguin Books. London, 2006. TOFFLER, Alvin. Üçüncü Dalga. çev. Selim Yeniçeri. Koridor Yayıncılık. İstanbul, 2008. VON HIPPEL, Eric. Democratizing Innovation. The MIT Press. Massachusetts. 2005.

\section{Makaleler}

ESTELLÉS-AROLAS, Enrique, Fernando González L. Guevara. “Towards an Integrated Crowdsourcing Definition.” Fournal of Information Science. 2012. Vol. 38. No. 2. 189-200.

HAYEK, Fried A. "The Use of Knowledge in Society." The American Economic Review. 1945. Vol. 35. No. 4. 519-530.

MEIER, Patrick, Rob Munro, “The Unprecedented Role of SMS in Disaster Response: Learning from Haiti”, SAIS Review, 2010. Vol. 30. No. 2. 90-103.

\section{Raporlar}

"10 Years of Impact", Ushahidi. 2018. https://www.ushahidi.com/uploads/casestudies/Impactport_2018.pdf (Erisim Tarihi: 20.03.2020).

HEINZELMAN, Jessica. Carol Waters. "Crowdsourcing Crisis Information in Disaster Affected Haiti", United States Institute of Peace. 2011. https://mirror.explodie.org/ Crowdsourcing\%20Crisis\%20Information\%20in\%20DisasterAffected\%20Haiti.pdf (Erişim Tarihi: 20.03.2020).

SCHAFFER, Jan. Mimi Onuhoa. Jeanne Pinder. "Guide to Crowdsourcing”, Columbia Fournalism School. 2016. https://core.ac.uk/download/pdf/161457016.pdf. (Erişim Tarihi: 20.02.2020).

\section{Internet Siteleri}

"How to Do it? A Different Way of Organazing Government". http://govinfo.library. unt.edu/911/report/911Report_Ch13.htm (Erişim Tarihi: 09.18.2019).

CLINTON, Hillary Rodham, "Remarks on Internet Freedom", https://2009-2017.state. gov/secretary/20092013clinton/rm/2010/01/135519.htm. (Erişim Tarihi: 14.03.2020)

FLETCHER, Pascal. "Post-Quake Recovery May Boost Haiti Telecoms Market." https://www.reuters.com/article/idUSN30159947 (Erisim Tarihi: 08.02.2020).

HOWE, Jeff. "The Rise of Crowdsourcing". https://www.wired.com/2006/06/crowds/ (Erisim Tarihi: 09.18.2019)

JEFFREY, Simon "Ushahidi: crowdmapping collective that exposed Kenyan election killings", https://www.theguardian.com/news/blog/2011/apr/07/ushahidi-crowdmapkenya-violence-hague (Erişim Tarihi: 14.03.2020).

ŞEKER, Sadi Evren. "Kitle Kaynak (Crowdsourcing)," http://mis.sadievrenseker.com /2015/04/kitle-kaynak-crowdsourcing/ (Erişim Tarihi: 12.02.2020). 